\title{
MANAJEMEN PEMBELAJARAN DI MADARASAH TERPENCIL (STUDI KASUS DI MI RIYADUL FALAH AIKPERAPA, AIKMEL, LOMBOK TIMUR)
}

\author{
Oleh: M. Musfiatul Wardi
}

\begin{abstract}
Abstrak
Tulisan ini bertujuan mengetahui Manajemen Pembelajaran pada madrasah pinggiran/terpencil yakni MI Riyadul Falah Aikprapa yang dilihat dari segi perencanaan, pelaksanaan, dan pengawasan.

Penelitian ini merupakan jenis penelitian deskriptif kualitataif dengan pendekatan studi kasus. Subyek dari penelitian ini adalah para pelaksana pengelolaan pembelajaran di madarasah yaitu kepala madarasah dan guru. Data dari penelitian ini diperoleh dengan cara wawancara, observasi dan dokumentasi, yang kemudian dianalisis secara kualitatif dengan menggunakan teknik analisis Interaktif (Model Huberman).

Hasil penelitian menunjukkan bahwa pengelolaan pembelajaran yang ada d $M I R F$ terdiri dari beberapa tahap, yaitu : (1) perencanaan pembelajaran dimulai dengan perumusan program madarasah, penyusunan RAPBM. Perencanaan pembelajaran disusun dengan membuat silabus berdasarkan standar isi dan penyusunan RPP, dengan melihat silabus dan RPP yang dibuat oleh madarasah lain, hal ini dilakukan karena keterbatasan yang dimiliki oleh MI Riyadul Falah. Penyusaian silabus dan RPP yang diambil dari madarasah lain dilakukan oleh setiap guru; (2) pelaksanaan pembelajaran belum berjalan dengan baik, karena kegiatan belajar mengajar belum efektif karena guru sering terlambat bahkan tidak masuk disebabkan oleh faktor geografis yang jauh serta kesibukan guru yang tidak hanya mengajar di MI, tapi di keseluruhan lembaga pendidikan yang bernaung di Yayasan Riyadul Falah Aikperapa dan kesibukan guru yang memenuhi kebutuhan ekonomi di luar. Kendala yang lain juga, siswa siswa tidak masuk karena persoalan jarak tempuh madarasah dari salah satu dusun jauh, harus melewati tengah hutan sebagai jalan pintas menuju madarasah. Selain itu, siswa di ajak oleh orang tua ikut ke ladang.(3) pengawasan pembelajaran pembelajaran telah dilakuan oleh kepala madarsah dan guru baik di kelas maupun di luar kelas. Evaluasi hasil belajar siswa telah dilaksanakan oleh guru untuk mengetahui tingkat ketuntasan pencapaian komptensi dasar siswa di MI. penilaian hasil belajar siswa dilaksanakan setiap akhir kompetensi dasar selsai, sesuai dengan beberapa indikator yang telah dibahas dengan mengacu kepada nilai-nilai kriteria ketuntasan minimum (KKM).
\end{abstract}

Kata Kunci : Manajemen Pembelajaran, Perencanaan, Pelaksanaan, Pengawasan dan Evaluasi 


\section{A. PENDAHULUAN}

Pendidikan merupakan suatu proses untuk menjadikan manusia agar mengenal potensi dirinya baik potensi jasmani, intelektual dan spiritual sehingga bisa menjadi warga negara yang baik melalui proses pembelajaran yang dilakukan secara sadar dan terencana. Hal ini sesuai dengan apa yang dinyatakan dalam undang-undang nomor 20 tahun 2003 tentang Sistem Pendidikan Nasional bahwa pendidikan adalah usaha sadar dan terencana untuk mewujudkan suasana belajar dan proses pembelajaran agar peserta didik secara aktif mengembangkan potensi dirinya untuk memiliki kekuatan spiritual keagamaan, pengendalian diri, kepribadian, kecerdasan, akhlak mulia, serta keterampilan yang diperlukan dirinya, masyarakat, bangsa dan negara. ${ }^{1}$

Dalam pasal 3 ayat 3 UU Sisdiknas 2003 juga dijelaskan bahwa fungsi dan tujuan pendidikan nasional yaitu mengembangkan kemampuan dan membentuk watak serta peradaban bangsa yang bermartabat dalam rangka mencerdaskan kehidupan bangsa, bertujuan untuk berkembangnya potensi peserta didik agar menjadi manusia yang beriman dan bertakwa kepada Tuhan Yang Maha Esa, berakhlak mulia, sehat, berilmu, cakap, kreatif, mandiri, dan menjadi warga negara yang demokratis serta bertanggung jawab.

Undang-undang ini merupakan pijakan dasar hukum dalam penyelenggaraan dan reformasi system pendidikan nasional. Selain itu, Undang-undang tersebut juga memuat visi, misi pendidikan nasional, serta strategi pembangunan pendidikan nasional, untuk mewujudkan pendidikan yang bermutu, relevan dengan kebutuhan masyarakat, dalam kehidupan global.

Visi pendidikan nasional dimaksudkan untuk mewujudkan system pendidikan sebagai pranata sosial yang kuat dan berwibawa yang berguna untuk memberdayakan semua warga Negara Indonesia agar berkembang menjadi manusia yang berkualitas, sehingga mampu dan proaktif menjawab tantangan zaman yang selalu berubah-ubah. Sementara misi pendidikan nasional adalah : (1) selalu mengupayakan perluasan dan pemerataan kesempatan memperoleh

1 Undang-undang Republik Indonesia Nomor 20 tahun 2003 tentang Sistem Pendidikan Nasional. 
pendidikan yang bermutu bagi seluruh rakyat Indonesia; (2) meningkatkan mutu pendidikan yang memiliki daya saing di tingkat nasional, regional, dan internasional; (3) meningkatkan relevansi pendidikan dengan kebutuhan masyarakat dan tantangan global; (4) membantu dan memfasilitasi pengembangan potensi anak bangsa secara utuh sejak usia dini hingga akhir hayat dalam rangka mewujdkan masyarakat belajar; (5) meningkatkan kesiapan masukan dan kualitas proses pendidikan untuk mengoptimalkan pembentukan kepribadian yang bermoral; (6) meningkatkan keprofesionalan dan akuntabilitas lembaga pendidikan sebagai pusat pembudayaan ilmu pengetahuan, keterampilan, pengalaman sikap, dan nilai berdasarkan standar yang bersifat nasional dan global; (7) mendorong peran serta masyarakat dalam penyelenggaraan pendidikan berdasarkan prinsip otonomi dalam konteks Negara Kesatuan Republik Indonesia. ${ }^{2}$

Berdasarkan visi dan misi pendidikan nasional, maka reformasi pendidikan terjadi dalam berbagai hal, diantaranya : penyelenggaraan pendidikan dinyatakan sebagai proses pembudayaan dan pemberdayaan peserta didik yang berlangsung sepanjang hayat, dimana dalam proses tersebut menyebabkan adanya pergeseran paradigma proses pendidikan, dari paradigma pengajaran ke paradigma pembelajaran.

Paradigma pengajaran, menitikberatkan peran pendidik dalam proses transformasi pengetahuan kepada peserta didik bergeser kepada paradigma pembelajaran dengan memberikan peran lebih banyak kepada peserta didik untuk mengembangkan potensi dan kreatifitas dirinya dalam rangka membentuk manusia yang memiliki kekuatan spiritual keagamaan, berakhlak mulia, berkepribadian, memiliki kecerdasan, memiliki estetika, sehat jasmani dan rohani, serta keterampilan yang dibutuhkan bagi dirinya, masyarakat, bangsa dan negara.

Perubahan tentang peran manusia dari paradigma manusia sebagai sumber daya pembangunan, menjadi paradigma manusia sebagai subyek pembangunan secara utuh. Pendidikan dalam hal ini harus mampu membentuk manusia yang memiliki kekuatan spiritual keagamaan, berakhlak mulia, berkepribadian, memiliki

2 Penjelasan Atas peraturan Pemerintah Republik Indonesia Nomor 19 Tahun 2005 Tentang Standar Nasional Pendidikan. 
kecerdasan, memiliki estetika, sehat jasmani dan rohani, serta keterampilan yang dibutuhkan bagi dirinya, masyarakat, bangsa dan Negara.

Perubahan tentang peran manusia dari paradigma manusia sebagai sumberdaya pembangunan, menjadi paradigma manusia sebagai subyek pembangunan secara utuh. Pendidikan dalam hal ini harus membentuk manusia seutuhnya yang digambarkan sebagai manusia yang memiliki karakteristik personal yang memahami dinamika psikososial dan lingkungan kulturalnya. Proses pendidikan seharusnya mencakup: (1) penumbuh kembangkan keimanan, ketakwaan, (2) pengembangan wawasan kebangsaan, kenegaraan, demokrasi, dan kepribadian; (3) penguasaan ilmu pengetahuan dan teknologi ; (4) pengembangan, penghayatan, apresiasi, dan ekspresi seni; serta (5) pembentukan manusia yang sehat jasmani dan rohani. ${ }^{3}$

Proses pembentukan manusia pada hakikatnya merupakan proses pembudayaan dan pemberdayaan peserta didik yang terintegrasi dengan lingkungan sosio kulturalnya dan pada gilirannya akan menumbuhkan individu sebagai pribadi dan anggota masyarakat yang berbudaya. Acuan penyelengGara pendidikan Standar nasional pendidikan adalah alat/sarana untuk memacu pengelola, penyelenggara, dan satuan pendidikan agar dapat meningkatkan kinerjanya dalam memberikan layanan pendidikan bermutu. Selain itu, merupakan perangkat untuk mendorong terwujudnya transparansi dan akuntabilitas publik dalam penyelenggaran system pendidikan nasional.Standar nasional pendidikan memuat kriteria minimal tentang komponen pendidikan yang memungkinkan setiap jenjang dan jalur pendidikan untuk mengembangkan pendidikan secara optimlal sesuai dengan karakteristik dan kekhasan programnya.

Lahirnya Undang-undang Sisdiknas merupakan wujud komitmen tertulis dari semua pihak untuk meningkatkan sumber daya manusia Indonesia, Indonesia saat ini sudah memasuki dunia kompetitif, dunia yang berhadapan dengan ketersediaan Sumber Daya Manusia (SDM) yang berkualitas. ${ }^{4}$ Salah satu cara meningkatkan

\footnotetext{
${ }^{3}$ Ibid..

${ }^{4}$ H. Isjoni, Menuju Maysarakat Belajar, Pendidikan dalam Arus Perubahan, (Yogyakarta : Pustaka Pelajar, September 2009), hlm.9
} 
sumber daya manusia adalah dengan meningkatkan pembangunan pendidikan, karena bangsa yang tidak peduli terhadap pembangunan pendidikan akan menjadi bangsa yang kerdil dan tersingkir dari persaingan global.

Peningkatan pendidikan Indonesia pun harus dilakukan secara merata bukan hanya milik orang kaya yang berduit ataupun wilayah perkotaan yang notabene dekat dengan pusat kekuasaan tapi juga wilayah-wilayah pelosok, seperti wilayah pegunungan, pesisir dan lain-lain. Hal ini dapat memperluas akses pendidikan, yang merupakan upaya agar semua anak di Indonesia memiliki kesempatan yang sama dalam mengenyam pendidikan, sehingga tercipta keadilan dalam pendidikan.

Perluasan akses dan pemerataan pendidikan yang berkualitas, melalui peningkatan pelaksanaan wajib belajar pendidikan dasar Sembilan tahun sehingga dapat memberikan kesempatan yang sama bagi semua peserta didik, dan dapat mempersempit perbedaan antara kota dan desa, termasuk perbedaan gender priawanita dan kaya-miskin. Dengan demikian pernyataan tersebut sejalan dengan UUD 1945 yang menyatakan bahwa setiap warga Negara berhak memperoleh pendidikan, dan wajib mengikuti pendidikan dasar dan pemerintah wajib membiayainya. (UUD 1945, pasal 30).

Namun, pemerataan pendidikan untuk semua rakyat Indonesia hingga saat ini masih terkendala, banyak hal yang menjadi penyebabnya seperti wilayah Indonesia yang terlalu luas, sehingga kurang terjangkau oleh peraturan ini, yang harus berlaku bagi pendidikan Indonesia seluruhnya. Negara Kesatuan Republik Indonesia (NKRI) adalah Negara kepulauan dengan rangkaian pulau besar dan kecil, menurut menurut data Departemen Dalam Negeri Republik Indonesia tahun 2004 adalah sebanyak 17.504 buah. 7.870 di antaranya telah mempunyai nama, sedangkan 9.634 belum memiliki nama. ${ }^{5}$ Dengan luasnya Indonesia memungkinkan timbulnya kendala mewujudkan kualitas pendidikan secara merata dan serentak. Sehingga tuntutan undang-undang meningkatkan kualitas pendidikan dapat dikatakan masih jauh. Kendala tersebut biasanya terjadi di kawasan terpencil dari Indonesia.

5 Wikipedia bahasa Indonesia, ensiklopedia bebas, di akses tanggal 8 April 2012. 
Penyebab lain, adanya dualisme system pendidikan Indonesia. Sekolah (SD/SMP/SMU) yang berada di bawah naungan Kementrian Pendidikan dan Kebudayaan nasional (Kemendiknas) dan pendidikan (MI/MTS/MA) di bawah naungan Kementrian Agama (Kemenag). Akibat dualisme ini, madarasahmadarasah (baca :MI) dalam panadangan sebagian masyarakat menjadi sekolah kelas dua, tidak maju, tidak berkualitas dan kurang mendapat perhatian lebih dari pemerintah daerah dan lain-lain. meski kendati secara yuridis pendidikan di naungan Kemendikbud dan Kemenag adalah sama.

Sementara itu, salah satu karakteristik dari madarasah ialah madarasah biasanya berlokasi di wilayah pedesaan dan pinggiran, lembaga pendidikan madrasah telah tumbuh dan berkembang sehingga merupakan bagian dari budaya Indonesia, karena ia tumbuh dan berproses bersama dengan seluruh proses perubahan dan perkembangan yang terjadi di dalam masyarakat. Kurun waktu cukup panjang yang dilaluinya, yakni kurang lebih satu abad, membuktikan bahwa lembaga pendidikan madarasah telah mampu bertahan dengan karakternya sendiri, yakni sebagai lembaga pendidikan untuk membina jiwa agama dan akhlak anak didik. Karakter itulah yang membedakan madarasah dengan sekolah umum.

Pertumbuhan lembaga pendidikan madarasah, sebagian besar dari swadaya masyarakat yang didirikan dengan niat agar dapat memberikan pendidikan yang lebih baik kepada anaknya untuk pendidikan umum dan agama. Hal ini tampak jelas status madrasah $91,5 \%$ berstatus swasta sedangkan yang berstatus negeri atau dikelola oleh pemerintah hanya berjumlah 8,5\%. Dan keuangan madarasah berasal dari peran serta masyarakat yang digunakan untuk gaji dan honor guru dan karyawan6.

Madarasah (baca : MI) Ibaratnya hidup segan mati tak mau. Atau sudah jatuh tertimpa tangga lagi. Artinya, madarasah Ibtidaiyah, memiliki aneka persoalaan, dan memiliki nasib yang kurang baik, lokasi di pinggiran, kurang diperhatikan pula oleh pemerintah. Citra ini melekat hingga sekarang. Sehingga wajar, bila madarasah (baca : MI) khususnya di kawasan daerah terpencil dan miskin tidak mampu

6 Direktorat Pendidikan Madarasah 2004-2005. 
bersaing dengan sekolah umum, apalagi bersaing dengan sekolah yang berada wilayah kota.

Namun, tidak adil bila membandingkan kondisi pendidikan antara wilayah kota dan desa terpencil karena keterjangkauannya yang menjadi kodrat alam, tapi hal ini tidak berlaku bagi pendidikan kritis karena mazhab kritis berpandangan bahwa pendidikan bukanlah untuk berkompetisi, bila idieologi kompetisi menjadi basis pendidikan maka pendidikan hanya diperuntukkan bagi mereka yang cerdas, pandai dan memiliki modal ekonomi dan sosial yang kuat ${ }^{7}$. Bagaimana pun letak geografis suatu daerah, pendidikan yang layak harus didapatkan oleh seluruh masyarakat Indonesia.

Salah satu daerah yang penyelengaraan pendidikan masih lemah adalah di desa Aikprapa, Aikmel, Lombok Timur yang merupakan penyangga bagian selatan dari kawasan Taman Nasional Gunung Rinjani (TNGR). Di kawasan ini berdiri sebuah lembaga pendidikan yang bernama Madarasah Ibtidaiyah (MI) Riyadul Falah yang bernaung di bawah yayasan pondok pesantren Riyadul Falah Aikprapa Kecamatan Aikmel, Lombok Timur NTB.

Observasi yang dilakukan peneliti di kawasan ini, diperoleh sekumpulan persoalan yang dihadapi oleh Yayasan Riyadul Falah, khususnya MI Riyadul Falah, kondisi obyektif yang ada di daerah tersebut, di antaranya : (1) tenaga pendidik yang kehadirannya tidak bisa maksimal. (2) inprastruktur jalan (akses jalan) yang buruk menuju Madarasah. (3) minimnya perhatian pemerintah daerah terhadap penyelenggaraan pendidikan madarasah di daerah ini.(4) pandangan masyarakat yang menganggap, proses pendidikan hanya di madarasah karena latar belakang pendidikan orang tua mayoritas setingkat SD (5) kondisi sarana prasarana pendukung, gedung sekolah yang minim.

Selain itu, belum optimalnya penyelenggaraan pendidikan di kawasan ini, yang merupakan penyangga Taman Nasional Gunung Rinjani (TNGR) juga disebabkan oleh tenaga pengajar yang umumnya berasal dari bawah gunung dan

7 M. Agus Nuryatno, Mazhab Pendidikan Kritis Menyingkap Relasi Pengetahuan Politik dan Kekuasaan, (Yogyakarta : Resist Book, Mei 2011), hlm.72 
hal ini mempengaruhi kegiatan proses belajar mengajar, terutama dalam ketepatan waktu karena penduduk asli tidak ada yang mencapai pendidikan tinggi.

Oleh karena itu, pengelolaan pembelajaran pada daerah terpencil harus mendaptakan perhatian khusus dari pemerintah, sehingga pemerataan di bidang pendidikan dapat dirasakan oleh semua lapisan masyarakat.

Dari pemaparan di atas, terlihat persolaan-persoalan yang dihadapi oleh Madarasah Ibtidaiyah (MI) Riyadul Falah seperti lokasi madarasah yang berada di pinggiran /terpencil, tenaga pendidik tidak maksimal dalam Kegiatan Belajar Mengajar (KBM), sarana prasarana yang dimiliki minim, dan pola pikir masyarakat yang mayoritas pendidikannya setingkat SD dan menganggap pendidkan hanya di bangku madarasah sehingga harapan sangat besar dibebankan kepada lembaga.

Dengan munculnya aneka macam problematika yang dihadapai Madarasah Ibtidaiyah (MI) Riyadul Falah yang berlokasi di daerah terpencil tersebut, menumbuhkan minat peneliti untuk melihat lebih dalam persoalan yang dihadapi oleh MI Riyadul Falah Aik Prapa. Untuk lebih fokusnya penelitian ini,dan keterbatasan dari peneliti sendiri, peneliti hanya akan meneliti tentang pengelolaan pembelajaran secara umum di MI Riyadul Falah. Fokus penelitian yang dibidik pegelolaan pembelajaran, yanlag mencakup perencanaan, pelaksanaan, pengawasan dan evaluasi pembelajaran.

Penelitian ini merupakan jenis penelitian deskriptif kualitatif dengan menggunakan pendekatan studi kasus. Dalam penelitian ditujukan untuk mendeskripsikan dan menganalisis fenomena, persitiwa, aktivitas sosial, sikap, kepercayaan, persepsi, pemikiran orang secara individual maupun kelompok ${ }^{8}$.

Menurut McMillan \& Schumacher yang dikutip Nana Saodih, penelitian kualitatif mempunya tujuan yaitu menggambarkan dan mengungkap (to describe and explore), dan menggambarkan dan menjelaskan (to describe and explore) menjelaskan ${ }^{9}$.

${ }^{8}$ Nana Syaodih Sukmadinata, Metode Penelitian Pendidikan, ( Bandung : Rosdakarya, cet.V, Februari 2009), h. 60

9 Ibid, h. 96 
Sementara Penelitian kasus adalah suatu penelitian yang dilakukan dengan cara intensif, terinci dan mendalam terhadap suatu organisasi, lembaga atau gejala tertentu. ${ }^{10}$ Dalam penelitian ini, peneliti berusaha untuk mengungkap fenomena pengelolaan pembelajaran Madarasah Ibtidaiyah (MI) Riyadul Falah ditengah keterpencilan maupun kekurangan yang dimiliki. Dan pertanyaan yang timbul adalah bagaimana pembelajarannya ditengah keterpencilan lokasi ini? Dengan demikian beberapa deskripsi yang digunakan nantinya diharapakn dapat menemukan pirnsip-prinsip dan penjelasan yang mengarah pada kesimpulan.

Penelitian ini dilaksanakan dalam konteks menyeluruh yaitu MI RF . penentuan sumber data dalam penelitian ini hampir sama dengan istilah pengambilan sampel dalam penelitian kuantitatif. Akan tetapi, perbedaannya terlihat dengan mengacu kepada apa yang dikutipkan oleh Sugiyono dari pernyataan Lincoln dan Guba. Penentuan sampel dalam penelitian kualitatif tidak didasarkan pada perhitungan statistik. Sampel yang dipilih berfungsi untuk mendapatkan informasi yang maksimum, bukan untuk digeneralisasikan. ${ }^{11}$

Penentuan subyek penelitian sebagai sumber data dilakukan dengan teknik snowball yaitu tehnik pengambilan sampel sumber data, yang pada awalnya jumlahnya sedikit, lama-lama menjdi besar ${ }^{12}$. Hal ini bertujuan untuk memperoleh data yang lengkap.

Oleh karena penelitian ini dititik beratkan pada pengelolaan pembelajaran, maka subyek penelitian adalah para pelaksana pengelola pembelajaran yaitu : Kepala madarasah, guru dan pengurus Yayasan (sebagai data pendukung). Apabila sumber-sumber data sebagaimana tersebut di atas dianggap telah memadai, artinya telah sampai kepada tarap redundancy (datanya telah jenuh, sehingga jika ditambah sumber lagi malah tidak akan memberikan informasi baru lagi). Hal ini senada dengan apa yang dikemukakan oleh Lincoln dan Guba bahwa "If the purpose is to maximize information, then sampling is terminated when no new information is

10 Suharsimi Arikunto, Prosedur Penelitian Suatu Pendekatan Praktek, (Jakarta : Rieneka Cipta, April 1998), h.131

11 Sugiyono, Metode Penelitian Pendidikan : Pendekatan Kuantitatif, Kualitatif, $R$ \& $D$ (Bandung : Alfabeta, 2010), h. 301.

12 Ibid. h. 300. 
forth-coming from newly sampled units; thus redundancy is the primary criterion." 13

Penelitian ini dilakukan di MI RF. Tempat ini dijadikan sebagai lokasi penelitian berdasarkan pertimbangan (1) letak geografisnya merupakan daerah pinggiran /pegunungan (2) MI Riyadul Falah termasuk dalam Kawasan penyangga TNGR di kecamatan Aikmel yang akses jalan menuju madarasah ini jauh, bila musim penghujan tiba, akses jalan menuju lokasi sangat sulit dimana jalan akan berlumpur dan licin.(3) daerah ini merupakan daerah pengembangan dari desa Aikmel Utara. (4) Lembaga-lembaga pendidikan di bawah naungan Yayasan Pesantren Riyadul Falah digerakkan oleh para pemuda, bahkan pimpinan Yayasannya. Dan pemudapemuda yang memplopori Riyadul Falah berasal dari luar Aik Prapa (bawah gunung).

Pengumpulan data merupakan salah satu bagian penting dari penelitian. Dengan beragamnya data di lapangan, perlu sekali seorang peneliti menggunakan beberapa teknik/metode pada saat pengumpulan data. Hal ini amat urgen karena dimungkinkan sekali adanya suatu metode yang terkadang sulit diterapkan untuk memperoleh data-data tertentu.

Beberapa metode pengumpulan data yang digunakan dalam penelitian ini meliputi:

(a) Pengamatan (observation); Mengobservasi adalah suatu ilmu umum yang memiliki arti semua bentuk penerimaan data yang dilakukan dengan cara merekam kejadian, menghitungnya, mengukurnya, dan mencatatnya. Dan metode observasi adalah suatu usaha sadar untuk mengumpulkan data yang dilakukan secara sistematis. ${ }^{14}$ Dan teknik observasi yang digunakan adalah Teknik Observasi langsung, di mana peneliti mengadakan pengamatan secara langsung (tanpa alat) terhadap gejala-gejala subyek yang diteliti. Melalui observasi, peneliti mengamati beberapa objek di lapangan, penelitaian ini dilakukan untuk mengamati kondisi keadaan proses pembelajaran serta ketersediaan dan kelengkapan saran dan prasarana di MI Riyadul Falah Aik Prapa, Aikmel Lombok Timur.

\footnotetext{
13 Ibid., h. 302.

${ }^{14}$ Suharsimi Arikunto, Prosedur Penelitian..., h. 225.
} 
(b) Wawancara; Tehnik pengumpulan data yang peneliti gunakan juga adalah wawancara. Wawancara merupakan pertemuan dua orang untuk bertukar informasi dan ide melalui Tanya jawab, sehingga dapat dikonstruksikan makna dalam suatu topic tertentu. ${ }^{15}$ Dengan tehnik wawancara semi terstruktur, artinya wawancara yang bebas di mana dalam pelaksanaannya peneliti dapat menemukan persoalan secara terbuka, dan informan diminta pendapat, dan ide-idenya. ${ }^{16}$ Tujuan dari wawancara, peneliti bertukar informasi dengan nara sumber sehingga mendapatkan data berupa perumusan kebijakan, terutama dalam penyusunan program kerja madarasah dan RAPBM dan lain-lain.

(c) Dokumentasi; Dokumentasi merupakan pelengkap dari penggunaan metode Wawancara dan observasi. Dokumentasi dapat berupa tulisan, seperti catatan harian, peraturan, kebijakan dan lain-lain.dan dokumentasi gambar berupa foto, sketsa dan lain-lain. Melalui metode dokumentasi, peneliti memperoleh datadata penting seperti deskripsi tentang obyek penelitian, uraian pendukung obyek, berikut keterangan yang lebih detail mengenai kebijakan atau aturan-aturan tertentu.

Analisa data merupakan proses mencari dan menyusun secara sistematis data-data yang diperoleh dari observasi, wawancara dan dokumentasi dengan mengorganisir data-data tersebut menjadi kategori-kategori, memilih dan memilah data sehingga mudah untuk dipahami dan mudah untuk mendapat kesimpulan dari penelitian yang telah dilakukan. ${ }^{17}$ Analisa data dilaksanakan sejak sebelum memasuki lapangan dan selama di lapangan. Sebelum memasuki lapangan, peneliti menganalisa data hasil studi terdahulu, atau data skunder, yang digunakan untuk menentukan fokus penelitian. Akan tetapi fokus tersebut masih bersifat sementara, yang kemudian berkembang setelah peneliti masuk dan selama di lapangan.

Sementara itu, analisis data model Miles dan Huberman digunakan selama peneliti berada di lapangan. Telah dipahami bersama bahwa aktivitas dalam analisis data kualitatif dilakukan secara interaktif dan berlangsung secara terus-menerus

\footnotetext{
15 Sugiono..., h. 317.

16 Ibid, h. 320.

17 Sugiono, Metode Penelitian..., h. 335.
} 
sampai tuntas, sehingga datanya sudah jenuh. Aktivitas dalam analisis data pada penelitian ini meliputi data reduction, data display, dan conclusion drawing/ verification.

\section{B. PEMBAHASAN}

\section{Perencanaan Pembelajaran di MI RF}

Sebagaimana paparan sebelumnya, pembelajaran merupakan proses yang dilakukan oleh individu maupun kelompok untuk memperoleh suatu perubahan prilaku, sebagai hasil dari pengalaman individu itu sendiri dalam interaksi dengan lingkungannya, sehingga akan lahir manusia pembelajar. Pada kata-kata manusia pembelajar terkandung perbuatan mengajar, mendidik, melatih, memberikan contoh, membangun keteladanan. Dalam pembelajaran, peserta didik menjadi sadar akan makna belajar, dapat belajar untuk belajar, guna mewujudkan hal tersebut diperlukan proses pengelolaan atau manajemen yang baik, dalam konteks ini manajemen pembelajaran di madrasah.

Manajemen pembelajaran madrasah selain diawali dengan perencanaan yang matang, juga harus didukung oleh pengorganisasian dan pengawasan pemimpin dalam hal ini adalah kepala madrasah. Manajemen pembelajaran memegang peranan penting dalam meningkatkan kualitas pendidikan. Dengan manajeman yang efektif diharapakan dapat terealisasikan tujuan yang ingin dicapai dengan memuaskan. Dengan manajemen yang efisien tujuan itupun dapat dicapai dengan tanpa pemborosan waktu, tenaga, material, dan finasial.

Dalam melaksanakan peran dan fungsinya, seorang kepala madrasah bekerjasama dengan semua unsur yang berada di madrasah terutama guru Madrasah Ibtidaiyah (MI) Riyadul Falah. Sebelum melaksanakan pembelajaran, pihak madrasah membuat program madrasah (Yayasan) dan penyusunan rencana anggaran yang dikenal dengan Rencana Anggaran dan Pendapatan dan belanja Madrasah (RAPBM). Program kepala madarasah juga mengikuti program kerja yang diterbitkan oleh Kementrian Agama.

"kami menyusun program madrasah setiap tahun ajaran baru, dan menjadi acuan kami bersama dalam melaksanakan proses belajar mengajar. Dalam penyusunan program, kami berkonsultasi dengan teman-teman guru yang di 
Yayasan Riyadul Falah dan pengawas Kelompok Kerja Madrasah (KKM) tentang bagaimana menyusun program ditambah pengalaman kami sejak yayasan Riyadul Falah pertama kali didirikan, kami selalu terlibat dalam membuat program, serta mengikuti program yang dibuat Kemenag."18

Pada penyusunan program di Yayasan Riyadul Falah Aikperapa, kepala madrasah melakukan pertemuan-pertemuan, baik formal dan non formal. Karena lokasi madrasah jauh dari tempat tinggal para guru, kepala madrasah bersama pimpinan yayasan aktif berkunjung ke rumah guru untuk membicarakan tentang rencana program dan perkembangan madrasah. Sebagaimana yang terungkap wawancara dengan kepala madrasah.

" karena lokasi madrasah dengan tempat tinggal guru, sebagai warga asli sini, ya kami harus pro aktif berkunjung ke rumah guru untuk membicarakan rencana program dan perkembangan madrasah, kami bersyukur ada kawankawan dari bawah gunung (Luar Aik Prapa) yang mau mengabdikan hidupnya di gawah sini, kendati kami belum bisa memberikan kesejahteraan yang mencukupi bagi guru-guru di sini " 19

Adapun pertemuan formal di MI Riyadul Falah dilaksanakan awal tahun ajaran baru, untuk mengetahui perkembangan pembelajaran selama satu semester dan mengevaluasi program yang disusun, serta menentukan tindakan selanjutnya, apabila ditemukan persoalan, dan pembagian tugas pada setiap semester. Tindakan yang dilakukan kepala madrasah tersebut menunjukkan, kepala madrasah berusaha dan siap dengan program yang dibuat. Artinya, dengan adanya penyusunan program, kegiatan kepala madrasah akan jelas, tidak menunggu adanya permintaan warga madrasah, tetapi berdasarkan inisiatif yang disesuaikan dengan keadaan. Setiap ada persoalan dan program yang dilaksanakan di madrasah, maka kepala madrasah akan meminta pertimbangan dari pengurus yayasan maupun guru-guru di lingkungan Yayasan Riyadul Falah Aikperapa. Dengan demikian, kepala madrasah menjalankan peran dan tugasnya.

Perencanaan pembelajaran merupakan satu hal mendasar, sebagai salah satu fungsi manajamen pembelajaran, dan memegang peranan penting

18 Wawancara dengan Kepala Madrasah tanggal 14 Mei 2012.

19 Wawancara dengan Ketua Yayasan dan Kepala Madrasah tanggal 14 Mei 2012 
diadakan dalam pembelajaran di madrasah. Untuk itu, kepala madrasah sebagai manajer merencanakannya dengan baik sebagai upaya mencapai tujuan pembelajaran. Dengan demikian, perencanaan merupakan suatu proses menetapkan tujuan dan sasaran, menentukan pilihan tindakan-tindakan konkrit yang akan dilakukan dan mengkaji cara-cara terbaik dalam mencapai tujuan.

Beberapa kegiatan perencanaan pembelajaran yang dilakukan guru di MI Riyadul Falah antara lain :

1) Pembagian tugas guru dalam pembelajaran, dan menentukan mata pelajaran yang akan diajarkan kepada siswa.

2) Memilih materi sesuai dengan Standar Kompetensi (SK), Kompetensi Dasar (KD), serta indikator. Hal ini dituangkan dalam perangkat pembelajaran. Dan perangkat pembelajaran seperti silabus dan RPP dilakukan dengan melihat silabus dan RPP yang dicopy dari madrasah lain, karena MI RF belum mampu menyusun secara mandiri.

3) Guru memilih dan menggunakan beberapa metode pembelajaran sehingga pelajaran yang disampaikan oleh guru dapat diterima dengan baik oleh siswa.

4) Menentukan indikator hasil belajar yang disesuaikan dengan kondisi karakteristik dan kemampuan siswa.

Jadi hal-hal diatas harus bisa dipersiapkan oleh guru pada waktu proses belajar mengajar berlangsung. Sehingga proses pembelajaran bagi siswa berlangsung dengan baik.

Hasil wawancara seorang guru MI Riyadul Falah mengungkapkan, perencanaan dilakukan oleh guru disiapkan sebelum pembelajaran berlangsung dan mengacu pada silabus yang dicopy dan dibagikan kepada guru. ${ }^{20}$ Kendala yang dialami oleh guru di MI dalam perencanaan pembelajaran adalah guru sering dituntut oleh kondisi, seperti membuat rencana yang bukan menjadi tanggung jawabnya, ini terjadi karena, guru terlambat datang bahkan tidak masuk mengajar.

20 Wawancara dengan Ilmiah, Am.a.Pd tanggal 18 Mei 2012. 
Keadaan ini sering terjadi di MI Riyadul Falah, dan lembaga lain yang bernaung di Riyadul Falah, karena lokasi madrasah yang jarak tempuhnya jauh dengan tempat tinggal guru. Pihak madrasah memaklumi hal tersebut dan hanya menghimbau guru untuk hadir tepat waktu. Namun pihak madrasah hanya bisa menghimbau, karena menjadi guru di Riyadul Falah bermodal keikhlasan. ${ }^{21}$

Selain itu, rencana pembelajaran atau pembuatan RPP tidak sepenuhnya dapat dilakukan oleh semua guru, karena keterbatasan waktu yang dimiliki guru, khususnya guru-guru yang mengajar tidak hanya di MI tetapi juga di SMP dan MA Riyadul Falah, akibatnya guru tidak fokus dalam pembuatan perangkat pembelajaran hanya mengandalkan silabus dan RPP yang di Copy dari madrasah lain. Selain itu, kendala lain yang dihadapi dalam mengembangkan perangkat pembelajarannya yaitu buku-buku pendukung penunjang yang dimiliki oleh madrasah masih minim.

Bila diperhatikan perencanaan pembelajaran yang dilakukan oleh guru di MI tidak sesuai dengan konsep perencanaan pembelajaran, karena terdapat berbagai kendala seperti kurangnya penunjang yang dimiliki MI Riyadul Falah, adanya guru yang tidak masuk, atau terlambat datang, bahkan terkadang tidak satupun guru yang masuk mengajar sehingga tiga (3) kelas dipegang langsung oleh hanya seorang guru sekaligus, dengan cara guru tersebut membagi waktunya di masing-masing kelas.

Adapun manfaat dari perencanaan antara lain : (a) sebagai alat atau standar pelaksanaan dan pengawasan agar tidak terjadi penyimpanganpenyimpangan dalam melaksankan pengajaran di sekolah, (b) dapat dilakukan pemilihan berbagai pilihan yang terbaik dalam penyusunan skala prioritas, (c) dapat menyesuaikan dengan perubahan-perubahan yang sedang terjadi pada saat berlangsungnya pembelajaran, (d) mempemudah penyesuaian dengan pihak-pihak yang terkait dengan kegiatan lain di sekolah, (e) meminimalkan

21 Wawancara dengan Kepala Madrasah MI Riyadul Falah tanggal 14 Mei 2012. 
pekerjaan yang tidak pasti dan menghemat sumber daya yang ada pada sekolah khususnya yang terkait dengan layanan pendidikan di sekolah ${ }^{22}$.

Disamping adanya perencanaan pembelajaran dari pelaksana pembelajaran (guru), dibutuhkan juga kepala madrasah yang merupakan pimpinan tertinggi dan bertanggung jawab sepenuhnya terhadap pengelolaan dan pelaksanaan pendidikan di madrasah. Dalam melaksanakan tugas fungsinya, kepala MI Riyadul Falah senantiasa melibatkan berbagai pihak terhadap kelangsungan program yang disusun, apalagi di MI Riyadul Falah persoalannya sangat komplek. Sehingga kepala madrasah tidak akan mampu menghadapi persoalan sendiri. Hal ini dijelaskan oleh Kepala Madrasah MI Riyadul Falah.

“ Dalam merumuskan pendidikan di MI Riyadul Falah, kami bekerja sama dengan guru, yayasan dan orang tua. Hal ini kami lakukan agar sesuai dengan apa yang diharapkan dan kami tidak dianggap jalan sendiri, serta kami tidak mungkin mampu menyelsaikan persoalan-persoalan yang ada di Madrasah Ibtidaiyah Riyadul Falah sendiri, sehingga kami membutuhkan saran dan dukungan dari warga madrasah" "23

Pihak madrasah senantiasa mengajak dewan guru merumuskan berbagai program atau kebijakan di madrasah. Selain itu, tidak lupa meminta pertimbangan dan masukan dari masyarakat maupun pihak guru yang berpengalaman di Riyadul Falah. Lebih-lebih madrasah memiliki kepentingan terhadap masyarakat.

\section{Pelaksanaan Pembelajaran di MI}

Setelah membuat perencanaan terhadap pembelajaran, tahapan berikutnya adalah pelaksanaannya. Terkadang, perencanaan yang direncanakan oleh guru kurang bisa terlaksana dengan baik, hal ini disebabkan oleh berbagai sebab. Dengan demikian, suatu perencanaan akan berjalan dengan baik, jika didukung oleh pelaksanaan yang baik pula.

22 Trianto, Model Pembelajaran terpadu dalam Teori dan Praktek, (Jakarta: Prestasi Pustaka Publiser, 2007), h. 38.

23 Wawancara dengan Kepala Madrasah 
Pelaksanaan pembelajaran merupakan rangkaian pembelajaran yang dilakukan secara berkesinambungan, meliputi tahap persiapan, penyajian, aplikasi dan penilaian. Pada tahap persiapan, hal-hal yang dilakukan guru adalah mempersiapakan ruang belajar, alat dan bahan, media, sumber belajar serta mengkondisikan lingkungan belajar sedemikian rupa sehingga peserta didik siap belajar. Selanjutnya pada penyajian, guru menyajikan informasi, menjelaskan cara kerja. ${ }^{24}$

Adapun dalam tahap pelaksanaan pembelajaran, guru diharapkan melakukan hal-hal sebagai berikut :

1) Tidak menjadi tokoh utama di dalam pembelajaran, tetapi menjadi fasilitator bagi siswa. Artinya, seorang guru harus memperhatikan kondisi siswa, seperti psikologi anak karena dipengaruhi oleh latar belakang keluarganya.

2) Memberikan tanggung jawab kepada siswa dengan memberi tugas, baik itu individu maupun kelompok sehingga dapat menumbuhkan rasa percaya diri siswa pada dirinya sendiri.

3) Guru mengakomodir ide-ide siswa dan memotivasinya dengan bahasa yang penuh kasih sayang.

Dalam melakukan hal tersebut, tentunya dalam pelaksanaan pembelajaran di kelas dimulai dengan dua langkah penting yaitu persiapan di kelas dan membuka pelajaran. Sebagai langkah awal, kedua hal ini akan menentukan proses selanjutnya.

Perencanaan pembelajaran di MI Riyadul Falah dapat dikatakan sudah direncanakan sesuai dengan kondisi daerahnya, kendati silabus dan RPP tidak seluruh guru membuat dan yang digunakan merupakan hasil dari madrasah lain, artinya guru MI RF telah berusaha semampunya ditengah keterbatasan yang dimiliki oleh madrasah dan keterpencilannya.

Permasalahan yang ditemukan dalam pelaksanaan pembelajaran adalah datang dari siswa, karena dipengaruhi oleh kondisi daerah dan keadaan pendidikan orang tua yang rendah sehingga orang tua siswa di MI RF sangat

24 E. Mulayasa, Menjadi Guru Profesional, hlm.98-99. 
berharap besar kepada madrasah dengan menyerahkan persoalan pendidikan hanya cukup di madaraah.

Akibatnya, guru yang mengajar harus kerja ektra, memperhatikan siswa dengan penuh kasih sayang, terutama pada pelajaran membaca dan berhitung, guru kesulitan karena siswa MI Riyadul Falah tidak ada yang mengikuti pendidikan pra-sekolah, karena kondisi yang tidak memungkinkan untuk masuk ke pra sekolah sehingga pelajaran tulis menulis guru mengalamai kesulitan. Selain itu, guru MI Riyadul Falah dalam proses pembelajaran terkendala masalah kelengkapan pembelajaran yang minim seperti buku-buku pelajaran atau media pembelajaran, persoalaan minimnya kelengkapan media pembelajaran ${ }^{25}$, guru MI Riyadul Falah mengatasinya dengan meminjam dan mengcopy ke guru lain yang ada di sekitar tempat tinggal mereka (luar Aik Prapa) dan memanfaatkan lingkungan sekitar madrasah sebagai media belajar siswa.

Pada waktu-waktu tertentu, siswa tidak masuk sekolah karena alasan cuaca, khususnya siswa yang berasal dari Dusun Merembuk, karena jarak tempuhnya $3 \mathrm{Km}$ dari madrasah dan harus melewati tengah hutan sebagai jalan pintas menuju madrasah, bahkan ada pula siswa tidak masuk sekolah karena orang tua mengajak anaknya ikut ke ladang, akibatnya proses kegiatan belajar mengajar tidak dapat terlaksana dengan baik ${ }^{26}$.

Permasalahan lain, sering terjadi adalah guru terlambat datang ke madrasah khususnya jam pertama, karena jarak tempuh dari rumah guru yang jauh dari madrasah, semua guru berasal dari bawah Gunung dan hanya pimpinan Yayasan dan Kepala madrasah yang merupakan penduduk asli Aik Perapa. bahkan guru tidak masuk mengajar karena persoalan geografis tersebut, lebih-lebih ketika musim penghujan tiba, akses jalan menuju Aikperapa berlumpur dan sangat licin untuk dilewati. Selain persoalan geografis, guru tidak masuk mengajar karena kesibukan diluar, misalnya mengajar di lembaga lain di Yayasan Riyadul Falah sehingga fokus di MI

25 Observasi terhadap fasilitas yang ada di MI RF.

26 Wawancara dengan Ilmiah, A.Ma.Pd. 
berkurang, mengurus keluarga, mencari kebutuhan dan memenuhi kebutuhan ekonomi lebih. ${ }^{27}$ Berdasarkan hasil di lapangan tersebut, dapat dikatakan bahwa proses pembelajaran di MI Riyadul Falah berjalan tidak efektif dan tidak maksimal.

Pelaksanaan KBM di MI diselenggarakan secara terjadwal dengan perhitungan waktu 1 jam pelajaran adalah 35 menit tatap muka. Kegiatan belajar mengajar meliputi kegiatan pembelajaran, kegiatan bimbingan baik oleh kepala madrasah maupun guru kelas, dan layanan bagi siswa yang belum mencapai ketuntasan belajar. Jika siswa yang belum mencapai ketuntasan batas minimal setiap mata pelajaran, maka guru MI RF akan memberikan perhatian lebih agar anak tersebut mencapai ketuntasan belajar yang diinginkan.

Kurikulum KTSP merupakan, suatu upaya menciptakan situasi yang memungkinkan berlangsungnya proses pembelajaran secara aktif dalam menyelseikan beban belajar yang ditempuh siswa. Pengelolaan pembelajaran berorientasi pada kemampuan guru mengatur kegiatan pembelajaran disesuaikan dengan konteks daerah yang letaknya jauh dari pusat kekuasaan (Kabupaten), sehingga ini dilakukan melalui berbagai metode dan strategi yang sesuai dengan kompetensi dasar, indikator, materi pelajaran, dan karakter siswa secara individual maupun kelompok sehingga siswa tuntas dalam pembelajarannya. Pada pelaksanaan pembelajaran, keaktifan guru dalam menciptakan dan menumbuhkan kegiatan belajar siswa sesuai dengan rencana yang disusun sangat dibutuhkan untuk keberhasilan pembelajaran. hal ini sudah dilakukan oleh guru MI Riyadul Falah. Karena Pembelajaran merupakan proses interaksi antara peserta didik dengan lingkungannya, sehingga terjadi perubahan perilaku ke arah yang lebih baik, dalam proses tersebut faktor internal dalam diri siswa, maupun eksetrnal yang datang dari lingkungan akan mempengaruhi proses perubahan itu ${ }^{28}$.

27 Wawancara dengan Ust. Saharuddin,

28 E. Mulyasa, Kurikulum Tingkat..., h. 255. 


\section{Pengawasan dan Evaluasi Pembelajaran di MI RF}

Hasil penelitian terhadap kegiatan pengawasan dan evaluasi atas pelaksanaan pembelajaran di Madrasah Ibtidaiyah (MI) Riyadul Falah, senantiasa diadakan pertemuan-pertemuan formal dan non formal di MI RF, seperti rapat internal guru MI, pertemuan seluruh guru yang ada di Yayasan Riyadul Falah dari MI, SMP dan MA, pertemuan dengan guru lain dari luar Riyadul Falah, dan pertemuan dengan wali murid, maupun berkonsultasi dengan Kelompok Kerja Madrasah (KKM) tingkat Kecamatan Aikmel. Sebagaimana yang diutarakan oleh seorang guru MI Riyadul Falah

" kami selaku guru bersama kepala madrasah rutin melakukan kegiatan pertemuan, di madrasah maupun di rumah-rumah guru, selain sebagai wahana silaturrahiem, kami juga membahas berbagai persolaan yang ada di madrasah, dalam pertemuan itu, kami mencari solusi bersama atas persolaan yang ada, bila kami tidak mampu memecahkannya, kami berkonsultasi dengan guru-guru Yayasan Riyadul Falah bahkan bertanya ke koordinator KKM yang ada di kecamatan"29

Dari penjelasan di atas diketahui, kegiatan pengawasan tetap dilaksanakan oleh kepala madrasah dengan mengadakan pertemuanpertemuan. Dalam pertemuan tersebut secara tidak langsung sesungguhnya kepala madrasah telah melakukan kegiatan pengendalian meskipun secara tidak tertulis.

Pengawasan juga dilakukan melalui kontrol yang dilakukan kepala madrasah dengan mengunjungi ruang kelas dan pengamatan langsung. kunjungan ini bisa bersifat rutin dan insidentil. Kunjungan ini merupakan bentuk dari pengawasan, dan hasilnya dapat dijadikan sebagai dasar pertimbangan dalam memberikan umpan balik dan upaya memperkuat komitmen guru yang mengabdikan dirinya di MI Riyadul Falah.

Disamping pengawasan dan evaluasi yang dilakukan oleh kepala madrasah, juga pengawasan yang dilakukan oleh Kemenag dan Dinas Pendidikan kabupaten Lombok Timur. Kedua lembaga pemerintah ini, setiap bulannya rutin diberikan lapor bulan yang berisi tentang keadaan madrasah. Ini

29 Wawancara dengan Bapak Zarkasi tanggal 27 Mei 2012. 
merupakan wujud dukungan unsur-unsur madrasah terhadap proses pembelajaran di MI yang dilakukan pemerintah. Pengawasan dari Kemenag secara langsung ke madrasah jarang dilakukan karena menurut Waka Kurikulum MI Riyadul Falah bahwa pengawas Kemenag sudah percaya terhadap pengelolaan pembelajaran yang dilakukan oleh pelaksana manajamen pembelajaran MI RF. Saat pengawas Kemenag mendatangi MI RF, pengawas menanyakan tentang sarana dan prasana,tenaga kependidikan, dan administrasi tata usaha (TU). ${ }^{30}$

Sementara itu, tujuan evaluasi adalah mengetahui seberapa jauh tingkat penguasaan dan ketuntasan belajar siswa. Kegiatan evaluasi pembelajaran di MI Riyadul Falah Aikperapa tetap dilaksanakan setelah materi pembelajaran selsei atau akhir semeseter. Hal ini bertujuan untuk mengetahui tingkat kemajuan dan perkembangan siswa dalam mata pelajaran tertentu.

\section{Hasil Penelitian}

Untuk memperbaiki hasil evaluasi yang dialakukan guru kepada siswa, dan tindak lanjut pengawasan yang dilakukan. Guru senantiasa diikutkan dalam pelatihan-pelatihan tentang kurikulum pembelajaran dan bebagi pengalaman/ berdiskusi dengan guru yang berpengalaman di Yayasan Riyadul Falah, karena yayasan berdiri sejak tahun 2004 dan mendirikan lembaga pendidikan SMP, dengan begitu guru SMP sering mengikuti mengikuti kegiatan pelatihan dan workshop yang dilaksanakan oleh lembaga pemerintah, apalagi penggerak guru MI merupakan guru SMP juga .

Sementara itu, pelatihan dan seminar yang sering diikuti oleh guru MI Riyadul Falah adalah pelatihan yang diadakan oleh LP NTB, tujuan diikutkannya para guru dalam acara pelatihan, guna memperbaiki pembelajaran yang dilakukan saat ini. Sehingga secara tidak langsung guru memiliki kemampuan yang baru dalam merencanakan pembelajaran.

Dalam perumusan berbagai kebijakan madrasah termasuk dalam hal manajamen pembelajaran, kepala madrasah senantiasa bekerjasama serta

30 Wawancara dengan Waka Kurikulm MI RF, Ust. Saharudin, S.Pd.I tanggal 26 Juli 2012. 
meminta pertimbangan, arahan, saran dukungan dari berbagai komponen madrasah. Kepala madrasah sebagai pemegang kebijakan penyelenggaraan pendidikan senantiasa melibatkan warga madrasah dalam setiap kegiatan termasuk saat perumusan berbagai kebijakan madrasah. Berbagai kebijakan yang bersifat urgen dan mendesak dirundingkan oleh kepala madrasah dengan guru, komite dan pimpinan yayasan.

Prinsip yang dipegang oleh kepala madrasah dalam menjalin hubungan dengan komite madrasah (masyarakat) maupun guru adalah komite madrasah (masyarakat) dan guru merupakan mitra, mediator dan ikut bertanggung jawab terhadap kelancaran penyelengaraan pendidikan di madrasah, sehingga setiap program dan kebijakan yang dijalankan dapat diterima oleh masyarakat.

Program madrasah yang dilaksanakan juga merupakan acuan yang diterbitkan oleh Kemenag Lombok Timur. Dalam penyusunan program di madrasah Ibtidaiyah Riyadul Falah, kepala madrasah senantiasa berkonsultasi dengan semua pihak, guru, komite dan pengurus yayasan karena pelaksanaan program madrasah merupakan tanggung jawab bersama semua komponen madrasah. Perencanaan program madrasah terlebih dahulu disusun, seperti penyusunan program kerja madrasah dan penyusunan Rencana Anggaran dan Pendapatan Belanja Madrasah (RAPBM). Setelah disusun, maka barulah disusun rencana manajemen/pengelolaan pembelajaran.

Penyusunan program kerja madrasah merupakan dasar yang dibuat sebelum madrasah menjalankan aktifitasnya dalam kegaitan belajar mengajar. Program madrasah disusun sebagai bahan merencanakan program di madrasah, termasuk didalamnya adalah penyusunan rencana anggaran madrasah.

Penyusunan rencana anggaran (RAPBM) memerlukan pengkajian dan pembahasan yang cermat dengan memperhitungkan sumber dana yang ada. Kerja sama kepala madrasah dan komite madrasah (masyarakat) dilaksanakan dalam bentuk ;

1) Kepala madrasah dan guru menyusun rencana anggaran, kemudian hasilnya tersebut dilaporkan ke pihak yayasan, selanjutnya pihak yayasan (ketua yayasan) bersama kepala madrasah dan beberapa guru menyampaikannya 
kepada komite madrasah (masyarakat) untuk diminta persetujuannya atas anggaran yang telah disusun. Pihak yayasan bersama-sama membahas, menganggarkan dan menyusun rincian biaya untuk setiap program yang telah disepakati.

2) Kepala madrasah dan komite madrasah (masyarakat/jama'ah) merumuskan lebih rinci anggaran madrasah, sehingga lahir kesepakatan biaya yang perlu dikeluarkan oleh orang tua.

Dengan demikian, dapat dikatakan bahwa peran dan kerja sama kepala madrasah dan komite madrasah sudah maksimal.

Jika penyusunan program kerja dan penyusunan anggaran telah dilaksanakan, selanjutnya guru menyusun perencanaan dalam pembelajaran. Seharusnya, perencanaan pembelajaran dimulai dari penyusunan silabus berdasarkan standar isi yang ada pada kurikulum KTSP dan dilaksanakan setiap awal semester, namun penyusunan silabus di sini tidak sepenuhnya dilakukan oleh MI Riyadul Falah, pihak madrasah (Waka Kur) hanya mengcopy dari madrasah lain yang berada di bawah gunung (perkotaan).

Hal ini dikarenakan MI Riyadul Falah belum siap menyusun sendiri silabus seperti yang menjadi harapan dari KTSP, meski demikian MI RF sudah mau berusaha belajar dari madrasah-madrasah lain dan guru-guru yang berpengalaman.

Sementara itu, KTSP merupakan singkatan dari Kurikulum Tingkat Satuan Pendidikan yang dikembangkan sesuai dengan satuan pendidikan, potensi sekolah/ daerah, sosial budaya masyarakat setempat, dan karakteristik peserta didik ${ }^{31}$. Dari pengertian tersebut, terlihat bahwa MI RF sangat memperhatikan kondisi masyarakat Aikperapa yang merupakan petani musiman dengan tingkat pendidikan masyarakat rendah, hal ini dapat mempengaruhi pembelajaran di MI RF sehingga guru dalam merencanakan pembelajaran sangat memperhatikan kondisi real tersebut, artinya guru tidak

31 E. Mulyasa, Kurikulum Tingkat Satuan Pendidikan (KTSP), Suatu Panduan Praktis,(Bandung : Rosda Karya, 2010), hlm. 8 
memaksakan kehendaknya agar siswa sama dengan sekolah lain yang ada di bawah gunung (perkotaan).

Siswa MI RF yang berlokasi di pinggiran membutuhkan perhatian lebih khusus, karena tingkat pendidikan orang tua yang rendah, belum lagi $50 \%$ dari orang tua siswa bekerja sebagai TKI/TKW di luar negeri, sehingga dapat dikatakan bahwa siswa MI RF kurang perhatian dan kasih sayang orang tua khususnya siswa yang orang tuanya menjadi TKI/TKW ke luar negeri sehingga guru harus memberikan motivasi yang kuat bagi siswa di MI RF. ${ }^{32}$

Selanjutnya, pembuatan Rencana Pelaksanaan Pembelajaran (RPP). RPP merupakan suatu perkiraan atau proyeksi guru mengenai seluruh kegiatan yang akan dilakukan baik guru maupun peserta didik, terutama dalam kaitannya dengan pembentukan kompetensi33. RPP berfungsi mendorong guru siap melakukan pembelajaran dengan perencanaan yang matang dan sebagai rencana pelaksanaan pembelajaran yang disusun secara sistematis dan menyeluruh. Jadi, bila kedua hal ini telah dilaksanakan, maka pembelajaran telah bisa dilaksanakan.

Konteks MI Riyadul Falah Silabus dan RPP yang digunakan, bukan dibuat oleh guru sendiri, tapi melihat (mengcopy) RPP yang dibuat oleh madrasah/sekolah lain. Idealnya seorang guru harus memperhatikan beberapa hal seperti yang dikemukakan B. Suryosubroto adalah ${ }^{34}$ : (a) karakteristik dan kemampuan awal siswa, (b) perumusan tujuan pengajaran (c) pemilihan bahan dan urutan bahan, (d) pemilihan metode mengajar, (e) pemilihan sarana / alat pendidikan, dan (f) pemilihan strategi evaluasi.

Hal di atas harus diwujudkan dalam perencanaan pembelajaran atau RPP yang menggambarkan prosedur dan pengorganisasian pembelajaran untuk mencapai satu kompetensi dasar yang ditetapkan dalam Standar Isi dan dijabarkan dalam silabus. Lingkup Rencana Pelaksanaan Pembelajaran paling luas mencakup 1 (satu) kompetensi dasar yang terdiri atas 1 (satu) indikator

\footnotetext{
32 Wawancara dengan Kepala MI Riyadul Falah

${ }^{33}$ E. Mulyasa, Kurikulum Tingkat Satuan, hlm.217

${ }^{34}$ B,Suryosubroto, Proses Belajar Mengajar di Sekolah (Jakarta : Rineka Cipta, 2002), hlm. 26
} 
atau beberapa indikator untuk 1 (satu) kali pertemuan atau lebih. Rencana Pelaksanaan Pembelajaran sekurang-kurangnya memuat tujuan pembelajaran, materi ajar, metode pengajaran, sumber pembelajaran. ${ }^{35}$ RPP juga biasa disebut dengan skenario pembelajaran, dari awal hingga akhir dari pembelajaran. ${ }^{36}$

Namun, bila dilihat dari kondisi geografis dan pengabdian guru di sini sangat luar biasa, istilah peneliti menyebutnya dengan 'Guru Terbang'. Guruguru MI RF tidak hanya mengelola dan menggerakkan lembaga MI akan tetapi mengelola keseluruhan lembaga pendidikan yang bernaung di Yayasan Riyadul Falah yakni Sekolah Menengah Pertama (SMP) dan Madrasah Aliyah Riyadul Falah serta Yayasan secara keseluruhan, hanya tiga (3) orang guru yang murni fokus mengajar di MI, dengan honor yang jauh tidak mencukupi, wajar terjadi demikian. Bila dipaksakan bahwa guru-guru MI RF harus membuat RPP sendiri setiap mengajar, dapat dipastikan guru-guru tidak akan mau mengajar di MI RF. Dapat dikatakan bahwa MI RF Aikperapa masih belum siap menggunakan model KTSP secara mandiri.

Hal yang dilakukan guru di MI RF tidaklah menjadi persoalan karena menurut E. Mulyasa, bila sebuah sekolah/madrasah belum siap menggunakan model KTSP secara mandiri, dapat menggunakan yang dibuat oleh Depdiknas atau yang dikembangkan oleh sekolah lain, tentunya menyesuaikannya dengan karakteristik sekolah masing-masing. ${ }^{37}$

Mencontoh silabus dan RPP madrasah lain, merupakan langkah awal yang akan menjadikan guru MI RF belajar dan memahami arti dan tujuan dari pembuatan RPP, serta menguasai secara teoritis dan praktis unsur-unsur yang terdapat dalam RPP. dan untuk penguasaan dan pembuatan RPP yang baik di MI RF secara mandiri membutuhkan proses yang lama, karena persoalan pendidikan di lembaga terpencil seperti Riyadul Falah begitu kompleks. Untuk itu, MI RF membutuhkan perhatian pemerintah di kawasan terpencil seperti Aik Prapa.

35 Pusat Pengembangan dan Pemberdayaan Pendidik dan Tenaga Kependidikan Tahun 2008

36 Muhaimin, dkk, Pengembangan Model KTSP pada Sekolah \& Madrasah, Jakarta : PT. Raja Grafindo Persada,2008), h. 149

37 E. Mulyasa, Kurikulum Tingkat..., h. 8 
Melihat apa yang telah dilakukan oleh guru MI Riyadul Falah, bahwa mereka telah melakukan fungsi yang ciri pekerjaan sebagai manajer dalam manajemen pendidikan yaitu, fungsi merencanakan yaitu pekerjaan seorang guru untuk menyusun tujuan belajar dan pengorganisasian (organizing) yakni pekerjaan seorang guru untuk mengatur dan menghubungkan sumber-sumber belajar, sehingga dapat mewujudkan tujuan belajar dengan cara yang paling efektif, efisien dan ekonomis. ${ }^{38}$

Pelaksanaan pembelajaran senantiasa dilakukan oleh guru dan kepala madrasah. Sebagai pelaksana pembelajaran, guru dan kepala madrasah telah melaksanakan proses pembelajaran, sehingga dapat berlangsung dengan baik, tetapi karena daerahnya terletak di daerah pinggiran dan terpencil, maka pembelajaran tidak berjalan sesuai dengan rencana pembelajaran yang disusun oleh guru dan kepala madarsah.

Permasalahan yang ditemukan adalah seringnya guru yang tinggal di bawah gunung tidak masuk mengajar, karena berbagai faktor. seperti faktor cuaca yakni bila musim penghujan tiba, akses jalan menuju madrasah yang berlumpur dan licin, berakibat guru tidak berani melewati jalan tersebut sehingga guru lebih memilih tidak masuk mengajar. Guru yang berasal dari kampung Aikprapa jumlahnya hanya seorang kewalahan, siswa sering dikumpulkan menjadi satu atau guru membagi waktunya beberapa menit untuk semua kelas bahkan pada waktu tertentu satu pun guru tidak ada yang masuk dari tingkat MI hingga MA di Riyadul Falah AikPerapa yang mengakibatkan siswa seolah kehilangan induk, meski pimpinan yayasan mengumpulkan seluruh siswa di aula.

Hal yang sama juga terjadi pada siswa yang rumahnya jauh dari madrasah, yang jarak tempuhnya sekitar $3 \mathrm{Km}$ dari madrasah yakni Dusun Merembuk, bila hujan turun, siswa tidak ada yang sekolah karena kondisi jalan yang buruk harus melewati jalan pintas di tengah hutan. Selain itu, ada siswa yang tidak masuk sekolah pada masa tertentu (musim panen) karena diajak orang tua

38 Ivor K.Davier (terj), Pengelolaan Belajar, (Jakarta : Cv.Rajawali, 1991), h. 35. 
untuk ke ladang. Guru dan pimpinan yayasan sering berkunjung ke rumah orang tua siswa memberikan pengertian bahwa anaknya harus masuk sekolah di waktu jam sekolah dan anaknya diajak ke ladang setelah sekolah usai.

Guru diutus mengikuti kegiatan-kegiatan mewakili Yayasan/Madrasah seperti, mengikuti kegiatan-kegiatan pelatihan yang dilaksanakan oleh LP NTB dan berkonsultasi dengan guru yang sudah berpengalaman di lembaga Riyadul Falah maupun guru luar Riyadul Falah dan pengawas KKM tingkat kecamatan Aikmel. Hal lain dilakukan oleh guru MI Riyadul Falah adalah pemberian perhatian dan motivasi terhadap belajar siswa, agar senantiasa tetap ditingkatkan, ini merupakan wujud dari Pre test yang memiliki kegunaan untuk menyiapkan peserta didik dalam proses belajar mengajar. agar pikiran siswa terfokus dalam pembelajaran dan mengetahui kemampuan awal siswa. Sementara itu, dalam membentuk kompetesni siswa, guru MI berusaha mewujudkan pembelajaran yang kondusif, tenang dan menyenangkan dengan memanfaatkan lingkungan sekitar sebagai temapat belajar yakni hamparan hutan yang ada di belakang madrasah.

Guru MI juga melakukan Post Test, fungsi post test adalah mengetahui tingkat penguasaan peserta didik terhadap kompetensi yang telah ditentukan, baik secara individu maupun kelompok dan sebagai bahan acuan melakukan perbaikan terhadap kegiatan pembelajaran dan pembentukan kompetensi yang telah dilaksanakan.

Bentuk dari Post Test yang dilakukan guru MI Riyadul Falah adalah mengulang-ulang materi pelajaran yang sudah disampaikan, dengan melakukan pengulangan tersebut, akan terlihat kemampuan siswa. Apabila siswa nampak tidak menguasai pelajaran, maka guru akan melakukan penekanan kepada siswa, yang bertujuan agar siswa dapat memahami materi yang disampaikan sehingga guru menjadi fasilitator bagi siswa.

Sementara itu, Ide-ide/masukan dari masyarakat diakomodir untuk pengembangan madrasah, dengan begitu pihak madrasah dapat dengan mudah mengkomunikasikan masalah sarana dan prasarana kepada masyarakat. Sarana dan prasaran pendidikan bisa terpenuhi, jika adanya kerjasama yang baik 
antara guru dan masyarakat, melalui komite madrasah maka tujuan yang direncanakan dapat terwujud.

Kegiatan pengawasan atas pelaksanaan pembelajaran di Madrasah Ibtidaiyah (MI) Riyadul Falah senantiasa dilakukan oleh guru dan kepala madrasah, bentuknya dilakukan melalui pertemuan-pertemuan formal yang diikuti semua guru dan tidak formal dengan berkunjung ke rumah guru yang terlibat dalam proses belajar mengajar di kelas.

Dengan kata lain kegiatan pengawasan dilakukan secara rutin dengan mengadakan rapat-rapat formal dan non formal, meminta masukan atas kemajuan siswa dan perkembangan madrasah. Dalam pertemuan tersebut secara tidak langsung sesungguhnya kepala madrasah telah melakukan pengawasan secara sistematis meski tidak tertulis.

Selain dengan mengadakan pertemuan rutin tersebut, kegiatan pengawasan dilakukan dalam bentuk pengendalian yang dilakukan kepala madrasah atau penunjukan wakil. Pengawasan ini dilakukan kepala madrasah guna mengetahui hasil yang dicapai benar-benar sesuai dengan rencana yang telah di susun sebelumnya.

Apabila hasil tidak sesuai dengan perencanaan yang ditentukan, kepala madrasah membahasnya dengan guru-guru Yayasan Riyadul Falah, sehingga persoalannnya dapat ditemukan dan diselseikan secara bersama-sama oleh semua komponen yang ada di Yayasan Riyadul Falah.

Sebagai badan pengontrol, kepala madrasah dapat memberikan evaluasi atas kinerja setiap personil. Kinerja yang dimaksud yaitu sejauh mana setiap personil mengaplikasikan dan melaksanakan tugs dan fungsinya yang telah dipercayakan kepadanya. Evaluasi pengajaran merupakan penilaian/penaksiran terhadap pertumbuhan dan kemajuan peserta didik kearah tujuan-tujuan yang telah ditetapkan, dan hasil penilaian dinyatakan secara kuantitatif dan kualitatif. $^{39}$ Pengendalian dilakukan melalui system evaluasi, khususnya mengukur kemampuan dan tingkat keberhasilan siswa dilaksanakan secara

${ }^{39}$ Harjanto, Perencanaan Pengajaran, (Jakarta : Rieneka Cipta, Sepetember 2003), h. 277. 
berkala melaui program ulangan harian, ujian semester dan penilaian-penilaian lainnya. Hal ini dilakukan mengetahui ketercapaian program pembelajaran, terutama kemajuan siswa.

Pengawasan atas pelaksanaan program madrasah dilakukan juga dengan menyusun laporan perkembangan program setiap bulan yang disampaikan kepada pemerintah seperti Kemenag dan Kemendiknas Kabupaten Lombok Timur. Laporan juga diberikan kepada orang tua siswa dalam bentuk informasi hasil belajar siswa atau raport yang diberikan setiap akhir semester.

Fungsi pengelolaan pengawasan (controlling) yang dilakukan pada setiap program kegiatan pembelajaran adalah usaha meneliti kegiatan-kegiatan yang telah dan akan dilaksanakan, apakah sesuai dengan rencana dan tujuan atau belum. Pengawasan sering juga disebut pengendalian yang berorientasi pada obyek yang dituju serta merupakan alat menyuruh orang-orang bekerja menuju sasaran yang dicapai.

Dari hasil penelitian terhadap pengendalian atas pelaksanaan pembelajaran di madrasah, senantiasa diadakan pertemuan-pertemuan formal di tingkatan madrasah (MI RF). Seperti apa yang diungkap seorang guru;

"Guru-guru dan kepala madrasah secara rutin melakukan pertemuan, guna membahas persoalan yang kami hadapi di madrasah" "40

Penjelasan di atas, menunjukkan bahwa kegiatan pengawasan dilakukan melaui kontrol yang dilakukan kepala madrasah terhadap semua komponen yang ikut serta dalam kegiatan proses pembelajaran di madrasah. Pelaksanaan pengawasan proses pembelajaran dapat melalui kunjungan ke ruang kelas dan pengamatan langsung di madrasah.

Secara keseluruhan, bahwa kepala madarsah dan guru telah melaksankan empat (4) fungsi yang merupakan ciri pekerjaan seorang guru sebagai manajer yaitu :

40 Wawancara dengan Bapak Zarkasi tanggal 27 Mei 2012 
Pertama, Merencanakan merupakan tugas seorang guru menyusun tujuan belajar, diwujudkan dengan mempelajari silabus sebelum melaksanakan pembelajaran.

Kedua, Mengorganisasikan. Ini adalah pekerjaan seorang guru untuk mengatur dan menghubungkan sumber-sumber belajar, sehingga dapat mewujudkan tujuan belajar dengan cara yang paling efektif, efisien dan ekonomis. Hal ini dilaksanakan oleh guru MI Riyadul Falah dengan memanfaatkan lingukungan sekitar sebagai media pembelajaran. sementara itu, kepala madrasah menjalankan fungsi ini dengan pembagian tugas-tugas kepada guru MI Riyadul Falah.

Ketiga, Memimpin. ialah pekerjaan seorang guru untuk memotivasi, mendorong dan mensimlusasikan murid-muridnya, sehingga mereka siap untuk mewujudkan tujuan belajar, hal ini diwujudkan oleh guru dengan memberikan perhatian lebih bagi siswanya, karena karakteristik wilayah Aikperapa yang pegunungan, dan anak-anak menjalankan kehidupannya sangat keras. Dan keempat, Mengawasi.merupakan pekerjaan seorang kepala madrasah maupun guru untuk menentukan apakah fungsinya dalam mengorganisasi dan memimpin di atas telah berhasil dalam mewjudkan tujuan yang ditetapakan. ${ }^{41}$

Beberapa Manajemen/Pengelolaaan Pembelajaran MI RF Aikmel Lotim

\begin{tabular}{|l|l|l|l|}
\hline \multicolumn{2}{|l|}{ Perencanaaan Pembelajaran } & Pelaksanaan & $\begin{array}{l}\text { Pengawasan dan } \\
\text { Evaluasi }\end{array}$ \\
\hline 1 & $\begin{array}{l}\text { Pengcopyan Silabus dan } \\
\text { RPP }\end{array}$ & $\begin{array}{l}\text { Waka Kurikulum yang } \\
\text { dibagikan ke guru }\end{array}$ & $\begin{array}{l}\text { Dilaksankan setiap awal } \\
\text { semseter }\end{array}$ \\
\hline 2 & Materi yang diajarkan & $\begin{array}{l}\text { Dilaksanakan berdasar } \\
\text { SK/KD }\end{array}$ & $\begin{array}{l}\text { Dilaksanakan setiap selsei } \\
\text { semster }\end{array}$ \\
\hline 3 & $\begin{array}{l}\text { Penggunaan Metode } \\
\text { pembelajaran }\end{array}$ & Setiap pembelajaran & Sesuai atau tidak \\
\hline
\end{tabular}

\footnotetext{
${ }^{41}$ Ivor K.Davier (terj), Pengelolaan...hlm.36
} 


\begin{tabular}{|l|l|l|l|}
\hline 4 & $\begin{array}{l}\text { apersepsi, presensi, } \\
\text { sebelum kegiatan inti }\end{array}$ & $\begin{array}{l}\text { untuk mengetahui kondisi } \\
\text { siswa sebelum belajar }\end{array}$ & Kesiapan siswa \\
\hline 5 & $\begin{array}{l}\text { Memberikan penjelasan } \\
\text { kepada siswa }\end{array}$ & kegiatan inti pembelajaran & $\begin{array}{l}\text { dengan mengetahui } \\
\text { pemahaman siswa }\end{array}$ \\
\hline 8 & Penilaian & secara lisan dan tertulis & $\begin{array}{l}\text { Setiap akhir komptensi } \\
\text { dasar }\end{array}$ \\
\hline
\end{tabular}

\section{PENUTUP}

Berdasarkan hasil penelitian dan pembahasan, dapat dikemukakan beberapa kesimpulan sebagai berikut :

1. Perencanaan pembelajaran di madrasah terpencil (MI Riyadul Falah) dimulai dengan perumusan program madrasah, penyusunan anggaran (RAPBM) agar proses pembelajaran terlaksana dengan baik. Sedangkan Perencanaan pembelajaran, dilakukan dengan mencontoh/mengcopy silabus dan RPP dari madrasah lain dan dilakukan oleh setiap guru karena MI RF, belum mampu menyusun silabus dan RPP secara mandiri.

2. Pelaksanaan pembelajaran tidak berjalan dengan baik dan kurang efektif, disebabkan oleh tenaga pendidik yang tidak dapat datang tepat waktu karena faktor guru berasal dari luar Aikperapa (bawah gunung), bahkan terkadang tidak masuk mengajar karena 'kesibukan' guru di luar dan kondisi cuaca yang tidak mendukung, serta guru ada yang belum fokus mengajar di Madrasah Ibtidaiyah. Selain itu, siswa pada waktu tertentu tidak masuk sekolah seperti pada musim penghujan, siswa yang berasal dari Merembuk tidak masuk sekolah karena jarak dari madrasah sekitar $3 \mathrm{Km}$ dan harus melewati tengah hutan untuk sampai ke madrasah. Dan ada juga, siswa tidak masuk sekolah karena ikut dengan orang tuanya ke ladang. Jsdi pelaksanaan pembelajaran perlu ditinjau ulang, guna perbaikan dimasa yang akan datang. 
3. Pengawasan pembelajaran dilakukan oleh kepala madrasah dan guru terhadap pembelajaran, baik di kelas maupun di luar kelas. Evaluasi hasil belajar siswa dilakukan guru untuk mengetahui tingkat ketuntasan pencapaian kompetensi dasar siswa. Penilaian terhadap hasil belajar siswa dilaksanakan setiap akhir kompetensi dasar selsei, sesuai dengan beberapa indikator yang telah ditentukan. sehingga dapat dilakukan perbaikan demi keberhasilan siswa dalam belajar.

\section{DAFTAR PUSTAKA}

Abu-Duhou, Ibtisam, School-Based Management (terj), Jakarta : PT.Logos Wacana Ilmu, 2002.

Agama RI, Departemen, Undang-undang Republik Indonesia Nomor 14 Tahun 2005, Jakarta: Dirjen Pendidikan Islam,2006.

Aqib, Zaenal, Profesionalisme Guru dalam Pembelajaran, Surabaya : Insan Cendikia, 2003.

Asmani, Jamal Ma'mur Manajemen Pengelolaan dan Kepemimpinan Pendidikan Profesional, Yogyakarta : Diva Press, Juni 2009.

Arikunto, Suharsimi \& Lia Yuliana, Manajemen Pendidikan, Yogyakarta: Aditya Media bekerjasama dengan Fakultas Ilmu Pendidikan Universitas Negeri Yogyakarta, 2009.

Arikunto, Suharsimi, Prosedur Penelitian Suatu Pendekatan Praktek, Jakarta : Rieneka Cipta, April 1998.

Bafadal, Ibrahim, Manajemen Peningkatan Mutu Sekolah Dasar, dari Sentralisasi menuju Desentralisasi, Jakarta : Bumi Aksara, 2009.

Basri, Hasan, Filsafat Pendidikan Islam, Bandung : Pustaka Setia, 2009.

Noer Aly, Hery, Ilmu Pendidikan Islam, Jakarta : Logos, cet.II, 1999.

Darmaningtyas, Pendidikan Rusak-Rusakan, Yogyakarta : LKIS, Juli 2005.

Djmarah, Syaiful Bahri \& Aswan Zain, Strategi Belajar Mengajar, Jakarta : Rhieneka Cipta, 2006.

Fattah, Nanang, Landasan Manajemen Pendidikan, Bandung : Rosda Karya, April 2000.

Gintings, Abdorrakhman, Esensi Praktis Belajar \& Pembelajaran,(Bandung : Humaniora, cet-4.ttp.

Hamalik, Oemar, Dasar-dasar pengembangan Kurikulum, Bandung : PT Remaja Rosdakarya, Cet ke-III Mei 2009.

Hasibuan, JJ. dan Moedjiono, Proses Belajar Mengajar, Bandung : PT Remaja Rosda Karya,2008.

Harjanto, Perencanaan Pengajaran, (Jakarta : Rieneka Cipta, Sepetember 2003).

Ihsan, Hamdani dan A. Fuad Hasan, Filsafat Pendidikan Islam, Bandung : Pustaka Setia, April 2007. 
Isjoni, H., Menuju Mayarakat Belajar, Pendidikan dalam Arus Perubahan, Yogyakarta : Pustaka Pelajar, September 2009.

Jaelani, Kadir, Profesionalisme Pengawas Pendais, Jakarta: Dirjen Pembinaan Kelembagaan Agama Islam Depag RI 2000.

Kunandar, Guru Profesional Implementasi KTSP dan Persiapan Menghadapi Sertifikasi Guru, Jakarta : Raja Grafindo Persada.

K.Davier, Ivor (terj), Pengelolaan Belajar, (Jakarta : Cv.Rajawali, 1991).

Mulyasa, E., Menjadi Guru Profesional : Menciptakan Pembelajaran Kreatif dan Menyenangkan, Bandung : PT. Remaja Rosdakarya,2005.

----------, Implementasi Kurikulum 2004, Panduan Pembelajaran KBK, Bandung : Rosda Karya, Januari 2005.

----------,Kurikulum Tingkat Satuan Pendidikan (KTSP), Suatu Panduan Praktis,(Bandung : Rosda Karya, 2010)

Mulyono, Manajemen Administrasi dan Organisasi Pendidikan, Yogyakarta : Ar-Ruzz Media, Cet.IV 2010.

Muhaimin, MA, Manajemen Pendidikan Aplikasinya Dalam Penyusunan Rencana Pengembangan Sekolah/Madrasah, Jakarta : Kencana, cet.II, 2009.

Muhaimin, dkk, Pengembangan Model KTSP pada Sekolah \& Madarasah, Jakarta : PT. Raja Grafindo Persada,2008).

Nasution, Azas-asas Kurikulum, Jakarta : Bumi Aksara, 2005.

Nata, Abudin, Filsafat Pendidikan Islam 1, Jakarta : Logos Wacana Ilmu, 1997.

Nurdin, Muhammad, Kiat Menjadi Guru Profesional, Yogyakarta : Prismasophie, April 2004.

Nuryatno, M. Agus, Mazhab Pendidikan Kritis Menyingkap Relasi Pengetahuan Politik dan Kekuasaan, Yogyakarta : Resist Book, Mei 2011.

Pidarta, Made, Landasan Kependidikan, Jakarta : Renika Cipta, 2000.

Pusat Pengembangan dan Pemberdayaan Pendidik dan Tenaga Kependidikan Tahun 2008.

Rivai, H.Veithzal dan Hj.Sylviana Murni, Education Management (Jakarta : Rajawali pers.2009.

Rosyada, Dede, Paradigma Pendidikan Demokratis, sebuah Model Pelibatan Masyarakat dalam Penyelengaraan Pendidikan, Jakarta : Kresindo, 2004.

Samani, Muchlas dkk, Pembinaan Profesi Guru, Jakarta : Depdiknas, 2003

Sanjaya,Wina, Kurikulum dan Pembelajaran, Bandung : Kencana Prenada Media Group, 2008.

Sardiman, Interaksi dan Motivasi Belajar Mengajar, Jakarta : PT. Raja Grafindo Persada, 2007.

Soedijarto, Memantapkan Sistem Pendidikan Nasional, Jakarta: PT Gramedia Widiya Sarana Indonesia, 1993.

Stoner, James A.F dkk, Management (terj), Prentice-Hall Inc, 1996.

Suryosubroto, B., Proses Belajar Mengajar di Sekolah, Jakarta : Rineka Cipta, 2002.

Suwardi, Manajemen Pembelajaran, (Surabaya : JP. Books.)

Sugiyono, Metode Penelitian Pendidikan : Pendekatan Kuantitatif, Kualitatif, $R \& D$, Bandung : Alfabeta, 2010.

Syaodih Sukmadinata, Nana, Metode Penelitian Pendidikan, Bandung : Rosdakarya, cet.V, Februari 2009. 
Terry, G.R. dan L.W Rue, Dasar-Dasar Manajemen, Jakarta : Bumi Aksara, Oktober 1993.

Trianto, Model Pembelajaran Terpadu dalam Teori dan Praktek, Jakarta : Prestasi Pustaka Publiser.

Uno, Hamzah B., Perencanaan Pembelajaran, Jakarta : Bumi Aksara, Mei 2009.

-----------, Profesi Kependidikan Problema, Solusi, dan Reformasi Pendidikan di Indonesia, Jakarta : PT. Bumi Akasara, September 2007.

Usman, Husaini, Manajemen Teori, Praktik, dan Riset Pendidikan, Jakarta : PT. Bumi Aksara, cet.I, Mei 2006.

Widoyoko, S. Eko Putro, Evaluasi Program Pembelajaran Panduan Praktis Bagi Pendidik dan Calon Pendidik, Yogyakarta : Pustaka Pelajar, Oktober 2010.

Wawasan Tugas Guru dan Tenaga Kependidikan, Depatemen Agama RI, Dirjen Kelembagan Islam Jakarta 2005

Yamin, Martinis, Profesionalisasi Guru dan Implementasi KTSP, Jakarta: Gaung Persada Press, Cet.II, 2007.

Zamroni, Paradigma Pendidikan Masa Depan, Yogyakarta : Bigraf Publishing, 2001.

BAPENAS

UU 1945 Pasal 30 ayat 1

UU Sisdiknas No 20 tahun 2003.

Undang-undang Republik Indonesia Nomor 20 tahun 2003 tentang Sistem Pendidikan Nasional.

Penjelasan Atas peraturan Pemerintah Republik Indonesia Nomor 19 Tahun 2005 Tentang Standar Nasional Pendidikan.

Wikipedia bahasa Indonesia, Ensiklopedia Bebas, diakses tanggal 8 April 2012.

Direktorat Pendidikan Madarasah 2004-2005.

BAPPEDA NTB 2010.

http://www.ntbterkini.com/2012/02/24/ipm-ntb-masih-posisi-32/ diakses 15 April 2012

http://id.shvoong.com/diakses tanggal 24 April 2012 